\title{
Polyunsaturated fatty acids status in blood, heart, liver, intestine, retina and brain of newborn piglets fed either sow milk or a milk replacer diet
}

\author{
JM Alessandri, B Goustard, P Guesnet, G Durand \\ Laboratoire de nutrition et sécurité alimentaire, Centre de recherche Inra de Jouy, \\ 78352 Jouy-en-Josas cedex, France
}

(Received 8 June 1995; accepted 14 December 1995)

\begin{abstract}
Summary - Docosahexaenoic (DHA) and arachidonic acids (20:4n-6) are deposited in large amounts in the developing neural tissues of the fetus and neonate. The suckling infants receive both fatty acids via the maternal milk, whereas formula-fed infants must synthesize them de novo from their respective precursors, linoleic (18:2n-6) and $\alpha$-linolenic (18:3n-3) acids. We compared the lipid status of 14- and 21-day-old piglets fed either natural milk or infant formula, with special emphasis on the resulting DHA and $20: 4 n-6$ levels in the neural tissues. The two diets presented similar ratios of precursors (18:2n$6 / 18: 3 n-3=14-16)$. The sow milk contained $20: 4 n-6(0.6 \%$ of total fatty acids) and very low levels of DHA $(<0.1 \%)$. Formula feeding resulted in higher deposition of DHA in the brain than sow milk feeding, whereas the brain content of 20:4n-6 was not altered. The brain DHA level was negatively correlated with the 18:2n-6/18:3n-3 ratio in the red blood cells (RBC). In contrast, it was not correlated with the DHA concentration in the circulating lipids. The results indicate that the very low amount of DHA in sow milk has no effect on the accumulation of DHA in the piglet's brain, and that natural milk and formula are not equivalent with respect to precursor bio-availability and processing. This difference could be the result of a higher absorption rate and/or the metabolic sparing of formula $18: 3 n-3$. The data support the view that the balance between the essential precursors in the circulating lipids is of vital importance for optimal deposition of DHA in the developing neural tissues.
\end{abstract}

docosahexaenoic acid / arachidonic acid / milk / brain / piglet

Résumé - Teneurs en acides gras polyinsaturés dans le sang, le cœur, le foie, l'intestin, la rétine et le cerveau de porcelets nouveau-nés nourris au lait de truie ou avec un lait de remplacement. L'acide docosahexaénoïque (DHA) et l'acide arachidonique s'accumulent dans les tissus nerveux au cours du développement périnatal. Les jeunes enfants allaités naturellement ingèrent directement ces deux acides gras contenus dans le lait maternel, tandis que les enfants recevant des laits reconstitués doivent en réaliser la synthèse de novo à partir de leurs précurseurs respectifs, l'acide linoléique (18:2n-6) et l'acide $\alpha$-linolénique (18:3n-3). Nous avons comparé le statut lipidique de porcelets âgés de 14 et 21 jours, allaités naturellement ou nourris avec un lait adapté, en examinant l'incidence du type d'allaitement sur la composition des structures nerveuses. Le rapport des précurseurs était iden- 
tique dans les deux régimes $(18: 2 n-6 / 18: 3 n-3=14-16)$, mais le lait de truie contenait de l'acide arachidonique $(0,6 \%$ des acides gras totaux) ainsi qu'une faible quantité de DHA $(<0,1 \%)$. Comparativement à l'allaitement naturel, l'allaitement artificiel s'est traduit par un dépôt cérébral du DHA plus élevé, tandis que celui de l'acide arachidonique restait inchangé. La teneur cérébrale en DHA était corrélée négativement avec le rapport 18:2n-6/18:3n-3 des hématies. En revanche, la teneur en DHA des hématies n'était pas corrélée avec celle du cerveau. Le faible apport en DHA du lait de truie n'a donc eu aucune incidence sur le dépôt de cet acide gras dans le cerveau. La biodisponibilité du 18:3n-3 du lait de truie n'était pas équivalente à celle du lait adapté. Cette différence pourrait s'expliquer par une vitesse d'absorption plus élevée et/ou par une plus grande épargne énergétique du 18:3n-3 contenu dans le lait adapté. Ces résultats confirment que la notion d'équilibre entre les deux précurseurs est prépondérante pour la mise en place du DHA dans les structures nerveuses.

acide docosahexaénoïque / acide arachidonique / lait / cerveau / porcelet

\section{INTRODUCTION}

Long chain polyunsaturated fatty acids (LCPUFA) play a key role during the period of organ growth in the fetal and postnatal life of mammals. In particular, the development of the central nervous system depends on the extensive deposition of LC-PUFA in the cell membrane phospholipids of the brain and retina (reviews: Koletzko, 1992; Ballabriga, 1994).

Docosahexaenoic acid (DHA, 22:6n-3), which is the major polyunsaturated fatty acid of the membrane discs in the outer segments of rod photoreceptors, has been associated with the movements of rhodopsin in the photoreceptive process (Anderson et al, 1974), and with the optimal development of visual-acuity (Neuringer et al, 1984; Carlson et al, 1993). Its increasing concentration in the retina correlates with the rapid maturation of the photoreceptor cells during the last part of gestation (Ballabriga, 1994). In the brain, synaptosomal membranes contain high amounts of LC-PUFA of both the $n-3$ and $n-6$ series, DHA and arachidonic acid (20:4n-6), respectively (Bourre et al, 1984). The level of brain DHA seems to be a pivotal factor for the development of learning activity (Yamamoto et al, 1987; Bourre et al, 1989) and exploratory behavior in the young animal (Wainwright, 1992). The achievement of a specific neural composition requires an appropriate supply of LC-PUFA during growth and development, both in the amount and of the balance between the $n-6$ and $n-3$ fatty acids. Although the fetal brain and liver possess the ability to convert the precursors into their LC-PUFA derivatives (Bourre et al, 1990), the developing fetus must depend largely on the placental transfer of maternal DHA. After birth, the DHA supply of maternal milk also seems necessary to ensure its normal accretion in the brain of the term infant (Makrides et al, 1994). Whether an exogenous supply of DHA is crucial for the optimal development of visual acuity in term infants, however, remains controversial (Makrides et al, 1993; Innis et al, 1994).

Both LC-PUFA, DHA and 20:4n-6, are normally present in maternal milk, while standard infant formulas supply only their respective essential precursors: linoleic acid (18:2n$6)$ and $\alpha$-linolenic acid (18:3n-3). The necessity of supplementing formulas with LC-PUFA, especially DHA, is still under debate (Guesnet and Alessandri, 1995), and the use of animal models for the in-depth nutritional evaluation of LC-PUFA requirements in humans remains necessary. The use of piglets as a model offers the advantage of having a similar perinatal timing of the brain growth spurt (Dobbings and Sands, 1979) and brain myelination (Sweasey et al, 1976), and also similarity in essential nutrient 
requirements and natural milk fatty acid composition (review by Innis, 1993).

The present study was designed to mimic the current feeding of young infants, fed naturally or artificially, by establishing the lipid status of newborn piglets. After receiving colostrum, piglets were fed either a milk replacer diet simulating commercially available infant formula, ie containing essential precursors (18:2n-6 and 18:3n-3), or sow milk containing both precursors and LCPUFA. At the end of the feeding period, the fatty acids levels in the blood, heart, peripheral and neural tissues were determined and compared.

\section{MATERIALS AND METHODS}

\section{Animals}

Official French regulations (No 87848 and 03056 ) for the care and use of laboratory animals were followed. Male and female newborn piglets of the Large White $x$ Pietrain strain were obtained from the Pig Breeding Research Unit, INRA Center of Saint-Gilles, Rennes, France. The sows were fed a typical rearing diet, containing $6 \%$ by weight of vegetable fats. The lipid part of this diet was composed of $26.6 \%$ saturated fatty acids (mainly $16: 0$ ), $29.7 \%$ monounsaturated fatty acids (mainly $18: 1 \mathrm{n}-9$ ), $39.6 \%$ $18: 2 n-6$, and $3.3 \% 18: 3 n-3$. Piglets weighing about $1.5 \mathrm{~kg}$ at birth were either kept on the farm and suckled by their natural mothers until sacrifice, or designated for formula feeding and taken from the sow $6 \mathrm{~h}$ after bith. During this time, the piglets designed for formula feeding received the colostrum. They were then housed in a special room, with controlled heating, moisture and light. The humidity was kept between 42 and $47 \%$, and the temperature was programmed from 30 to $26^{\circ} \mathrm{C}$ with two descending steps of $2{ }^{\circ} \mathrm{C}$ every 3 days. Piglets were fasted for $6 \mathrm{~h}$ before being given free access to feeders secured to the cage wall. The formula was mixed and provided twice a day. All the artificially reared piglets ingested the formula spontaneously and handfeeding was not necessary. The total intake comprised between 0.5 and $1 \mathrm{~L} /$ day, the quantity available being adjusted daily to achieve an average growth rate of about $250 \mathrm{~g} /$ day. All the animals survived, with normal weight gains (fig $1 \mathrm{~A}$ ). In each feeding group, four to five piglets were killed at 1,14 or 21 days of age. They were fasted overnight, anesthetized by electronarcosis and immediately killed by bleeding. The piglets of the same age and of the same feeding group were issued from two different litters which were randomly chosen among the six litters assigned to the experiment.

\section{Formula composition}

The artificial milk powder was manufactured by Diépal-nsa, Research Center of Steenvoorde (CREST), France. Its fatty acid composition (table 1) was identical to that of an infant formula, but the macronutrient formulation was adapted to meet the specific requirement of piglets (Hrboticky et al, 1989). The formula contained (in \% by weight): casein (15), lactoserum proteins (15), carbohydrates (30), mineral and vitamin mix (3), and a blend of vegetable oils ( 30 ) composed of palm, coconut, sunflower and rapeseed oils. The powder contained $5.2 \mathrm{mg} \%$ of $\alpha$-tocopherol. The powder was stored at $4^{\circ} \mathrm{C}$ throughout the feeding trial. The milk was prepared daily by adding water to the powder at $200 \mathrm{~g} / \mathrm{L}$. The final milk was not stored more than one night at $4{ }^{\circ} \mathrm{C}$.

\section{Collection of tissues and extraction of total lipids}

\section{Milk}

The milk was collected at birth (colostrum) and at 14 and 21 days postpartum. The total lipids were extracted three times from $200 \mathrm{mg}$ of lyophilized milk, or from the formula powder, with $3 \times 4 \mathrm{~mL}$ of chloroform/methanol/butylhydroxytoluene (BHT) $(2: 1,0.02 \%, v / v / W)$. After centrifugation, the three supernatants were pooled and one volume of $\mathrm{NaCl} 0.73 \%$ was added to four volumes of supernatant (Folch et al, 1957). The total lipids contained in the final bottom phase were washed with one volume of chloroform/ methanol/water $(3: 48: 47, v / v / v)$, dried under a nitrogen stream, and were saponified with $\mathrm{KOH}$ $10 \%$ in ethanol. Free fatty acids were generated with $250 \mu \mathrm{L} \mathrm{HCl}$, and then methylated ( $30 \mathrm{~min}$ at 

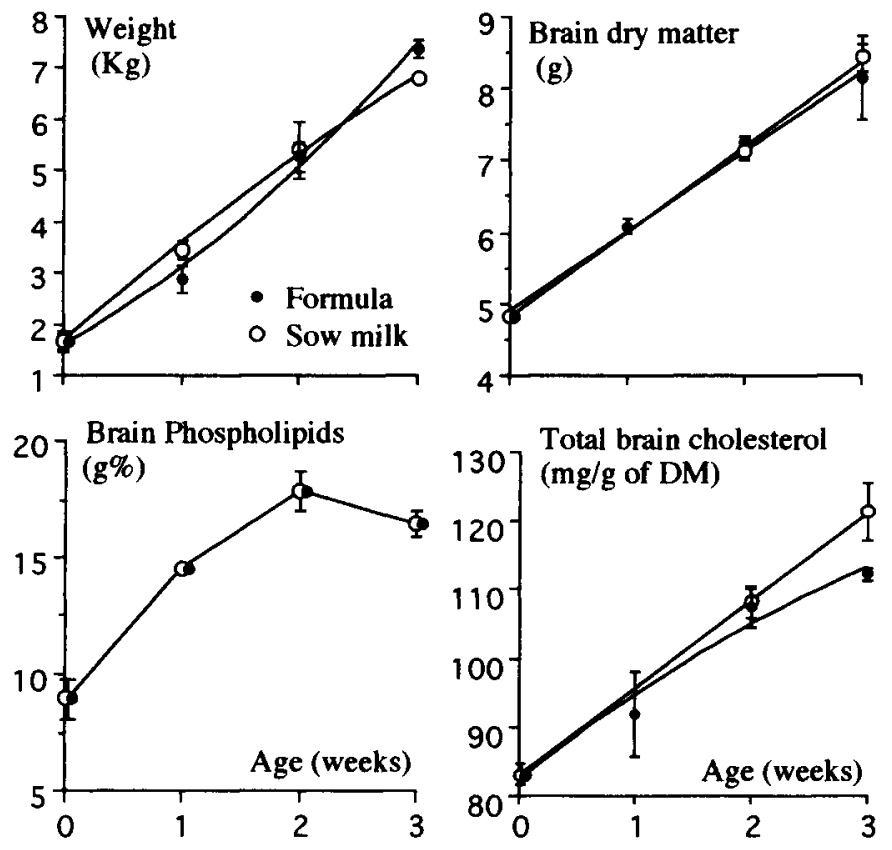

Fig 1. Growth parameters for formula and sow milk fed piglets, from birth to 3 weeks post-partum. A: weight gain; $B$ : brain growth; C: phospholipid deposition in brain; D: cholesterol deposition in brain.

$70{ }^{\circ} \mathrm{C}$ ) in methanol containing $\mathrm{HCl} 3 \%$ and dimethoxypropane $4 \%(\mathrm{v} / \mathrm{v})$. Fatty acid methyl esters were extracted with $1 \mathrm{~mL}$ hexane without any evaporation to avoid the loss of short and medium-chain esters.

\section{Blood}

Blood (5-10 mL) was collected at the time of bleeding with heparin as anticoagulant. After centrifugation, the plasma was collected and the red blood cell $(\mathrm{RBC})$ pellet was washed twice with $20 \mathrm{mM}$ Tris- $\mathrm{HCl}, 150 \mathrm{mM} \mathrm{NaCl}, 1 \mathrm{mM}$ ethylenediaminetetraacetate (EDTA) $(\mathrm{pH} \mathrm{7.4)}$. The total lipids were extracted from the RBC with isopropanol and chloroform (Rose and Oklander, 1965), and from the plasma with chloroform and methanol (Bligh and Dyer, 1959).

\section{Intestine}

The proximal segment of jejunum $(30 \mathrm{~cm}$ posterior to duodenum) was excised and rinsed with a phosphate-buffered saline solution (PBS), composed of $10 \mathrm{mM}$ sodium phosphate, $2.7 \mathrm{mM} \mathrm{KCl}$, and $137 \mathrm{mM} \mathrm{NaCl}(\mathrm{pH} 7.4)$. The segments were placed in $15 \mathrm{~mL}$ tubes filled with PBS containing $1.5 \mathrm{mM}$ EDTA and $50 \%$ glycerol $(\mathrm{v} / \mathrm{v})$. The tubes were stored at $-80^{\circ} \mathrm{C}$ until extraction of intestinal cells. The intestinal segments were thawed and rolled up and tied along a stainlesssteel rod $(0.5 \times 40 \mathrm{~cm})$. Each rod was immersed into a $35 \mathrm{~cm}$ long tube full of PBS containing 1.5 $\mathrm{mM}$ EDTA, $0.1 \%(\mathrm{w} / \mathrm{v})$ bovine serum albumin (fatty acid free) and $1 \mathrm{mM}$ dithiothreitol ( $\mathrm{pH} 7.4)$. The rod's tip was clipped to the mobile head of a vibration apparatus, and the mucosa was entirely scoured by producing several longitudinal, shortlived vibrations (Alessandri et al, 1993). The released epithelial cells were washed with PBS, and the total lipids of the pelleted cells were extracted according to the method of Folch et al (1957).

\section{Retina}

The eyes were removed and the anterior segment, lens and vitreous humor were discarded. The retina was detached from the retinal pigment epithelium according to the procedure of Chen et al (1992). The eyecups were incubated under gentle stirring at room temperature in a $\mathrm{Ca}^{2+}$-free Ringer buffer containing $118 \mathrm{mM} \mathrm{NaCl}, 4.7 \mathrm{mM}$ 
Table I. Fatty acid composition (\% by weight of total fatty acids) of formula and colostrum and sow milk (14 and 21 days postpartum).

Fatty acids

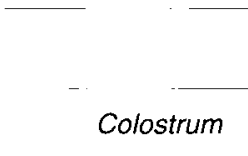

6:0

8:0

10:0

12:0

14:0

16:0

18:0

20:0

22:0

$\Sigma$ SFA

$16: 1 n-9$

16:1n-7

18:1n-9

18:1n-7

20:1n-9

$\sum$ MUFA

$18: 2 n-6$

18:3n-6

20:2n-6

20:3n-6

$20: 4 n-6$

$\sum n-6$ PUFA

$18: 3 n-3$

$20: 3 n-3$

$22: 5 n-3$

22:6n-3

$\sum n-3$ PUFA

$\sum$ unidentified

$18: 2 n-6 / 18: 3 n-3$

$\sum n-6 / \sum n-3$

\section{Sow milk}

14 days
Formula

21 days
0.2

1.9

1.6

1.6

5.5

19.8

5.5

0.3

0.3

$38.3 \pm 3.8 \quad 47.4$

$0.4 \pm 0.0 \quad 0.2$

$7.2 \pm 0.7$

$35.2 \pm 3.5$

33.7

0.9

34.8

16.5

$12.0 \pm 1.2$

$0.2 \pm 0.0$

$0.4 \pm 0.1$

$0.1 \pm 0.0$

$0.6 \pm 0.1$

$13.2 \pm 1.3$

16.5

$0.5 \pm 0.1$

$0.7 \pm 0.1$

1.2

$0.1 \pm 0.0$

$0.1 \pm 0.0$

$0.2 \pm 0.0$

$0.1 \pm 0.0$

$<0.1 \pm 0.0$

$1.0 \pm 0.1$

1.2

$1.4 \pm 0.1$

$16.4 \pm 2.6$

13.6

$13.0 \pm 3.2$

The mean values of three individual samples per time period are given. SFA: saturated fatty acids; MUFA: monounsaturated fatty acids; PUFA: polyunsaturated fatty acids.

$\mathrm{KCl}, 1.17 \mathrm{mM} \mathrm{KH}_{2} \mathrm{PO}_{4}, 1.17 \mathrm{mM} \mathrm{MgSO}_{4}, 5.6 \mathrm{mM}$ D-glucose, $35 \mathrm{mM} \mathrm{NaHCO}_{3}$, and $1.0 \mathrm{mM}$ EDTA (pH 7.4). After detachment, the retinal leaf was lacerated and stored at $-80^{\circ} \mathrm{C}$ until delipidation (Folch et al, 1957).

\section{Liver, brain and heart}

The whole fresh organ was excised, carved up, rinsed with $9 \mathrm{~g} / \mathrm{L} \mathrm{NaCl}$, drained and weighed. The crude matter was lyophilized and the total lipids 
were extracted (Folch et al, 1957) after a thorough homogenization of the dry powder.

\section{Analysis of tissue fatty acids}

\section{Separation of lipids}

The total phospholipids (PL) were separated from the neutral lipids by filtration through silica cartridges (Juaneda and Rocquelin, 1985). The liver and plasma triacylglycerols (TG) were further isolated using thin layer chromatography with hexane/diethyl ether/formic acid (80:20:1, v/v/v) as migration solvent. The different phospholipid classes of heart, RBC, intestinal cells and neural tissues, were separated by high performance liquid chromatography according to the procedure of Christie (1985). The total phospholipids were loaded onto a $25 \mathrm{~cm} \times 7.5 \mathrm{~mm}$ silica column (Lichrosorb SI 60), and the isolation of phosphatidylethanolamine (PE), phosphatidylcholine (PC) and cardiolipins (CL), was achieved at a flow rate of $2.5 \mathrm{~mL} / \mathrm{min}$, using a linear gradient of two solvent mixtures composed of hexane, isopropanol, chloroform and water.

\section{Gas chromatography}

Fatty acid methyl esters were produced by reacting $\mathrm{PL}, \mathrm{PC}, \mathrm{PE}$ and $\mathrm{CL}$ (20 $\mathrm{min})$, and TG (40 $\mathrm{min})$, with $10 \% \mathrm{BF}_{3}$ in methanol at $90{ }^{\circ} \mathrm{C}$ (Morrison and Smith, 1964). The methyl esters were analyzed using a gas chromatograph equipped with an 'oncolumn' injector, and a CP Wax $52 \mathrm{CB}$ (Chrompack, Midelburg, The Netherlands) bonded fused-silica capillary column $(50 \mathrm{~m} \times$ $0.3 \mathrm{~mm}$ (D). The oven temperature was programmed for $79-140-205^{\circ} \mathrm{C}$, at a heating rate of $9^{\circ} \mathrm{C} / \mathrm{min}$ for the first step, and $3^{\circ} \mathrm{C} / \mathrm{min}$ for the second step. The fatty acid methyl esters were automatically integrated and identified by comparison with standard compounds. All compositions were expressed as a percentage (by weight) of the total fatty acids.

\section{Statistical analysis}

Results were compared between the two groups using ANOVA. The signification of differences between diets at 14 and 21 days of age was evaluated using Fisher's test.

\section{RESULTS}

\section{Fatty acid composition of infant formula and sow milk}

The main differences between the infant formula and sow milk (table I) consisted in the high levels of short- and medium-chain fatty acids (C6:0 to C12:0) found in the formula, while $16: 1 n-7$ and LC-PUFA were present only in the sow milk. The levels of the two essential fatty acids, $18: 2 n-6$ and 18:3n3 , were slightly higher in the formula than in the mature sow milk, but both diets presented similar ratios of these precursors (18:2n-6/18:3n-3 = 14 to 16$)$. Sow milk supplied LC-PUFA of both the $n-6(20: 2 n-6$, $20: 3 n-6$ and $20: 4 n-6)$ and the $n-3$ series (20:3n-3, 22:5n-3 and 22:6n-3). The sum of $\mathrm{n}-3$ fatty acids in the sow milk ( $1 \%$ of total) matched the level of $18: 3 n-3$ in the formula $(1.2 \%)$. The whole PUFA decreased from birth to 14 days postpartum, mainly at the expense of the monounsaturated fatty acids.

\section{Weight gain, brain growth and composition}

The growth parameters from birth to 3 weeks postpartum are shown in figure 1 . Both groups had similar body weights (fig $1 \mathrm{~A}$ ), brain growth (fig $1 \mathrm{~B}$ ) and rates of $P L$ deposition in the brain matter. This last parameter increased significantly during the first 2 weeks postpartum. After that it levelled off at about $170 \mathrm{mg} \mathrm{PL} / \mathrm{g}$ of dry matter (DM) (fig 1C). Regardless of diet, the PL content in the whole brain increased threefold from birth to 3 weeks of age, with an accretion rate of $57 \pm 2.7 \mathrm{mg} /$ day (mean \pm $\mathrm{SE}$ ), and the amount of total cholesterol increased about 2.4-fold, with a mean accretion rate of $27 \pm 1.3 \mathrm{mg} /$ day. Formula feeding resulted in a significantly lower accretion of brain total cholesterol than maternal 
milk feeding (fig 1D). At 21 days of age, the formula-fed piglets had lower levels of unesterified cholesterol in the brain than sow milk those fed on $(56.4 \pm 0.8 \mathrm{mg} / \mathrm{g}$ of dry matter (DM) vs $63.9 \pm 1.5 \mathrm{mg} / \mathrm{g}$ of $\mathrm{DM} ; P<$ $0.001)$. On the other hand, the deposition rate of cholesterylesters was similar in both groups $(55.7 \pm 1.4 \mathrm{mg} / \mathrm{g}$ DM vs $57.4 \pm 2.9$ $\mathrm{mg} / \mathrm{g}$ of $\mathrm{DM})$.

\section{PUFA levels in blood, cardiac, liver, and intestinal lipids: comparison between formula and sow milk feeding}

\section{$18: 2 n-6$ and $18: 3 n-3$}

At 14 and 21 days of age, the formula-fed piglets had significantly higher $18: 2 n-6$ contents in heart, blood and peripheral tissues than sow-milk-fed piglets (table II). The same tendency was observed in the neural tissues, but the difference was significant only in the brain PL of 14-day-old piglets and in the retinal PC of 21-day-old piglets. It should be noted that the plasma PL and cardiac PE contained 2.4-fold more $18: 2 n-6$ in the formula-fed group than in the maternally fed one, while the formula contained 1.4-1.5-fold more 18:2n-6 than the mature sow milk. The 18:3n-3 levels were also about twofold higher in the lipid fractions of the formula group compared to the natural reference (table III). The 18:2n-6 level in the plasma PL of sow-milk-fed piglets (13\% of total fatty acids) matched that of the maternal milk TG $(12 \%)$, whereas the 18:2n-6 level in the formula groupplasma PL was twice as high as its proportion in the original formula ( 31 vs $16 \%$, table II). In contrast, all 18:3n-3 levels were generally below those found in the diet for both groups (table III). Finally, these differences in the status of precursors resulted in lower ratios of $18: 2 n-6$ to $18: 3 n-3$ in the lipid fractions of the formula-fed piglets, especially in the RBC and plasma PL (fig 2). Thus, identical ratios of $18: 2 n-6$ to $18: 3 n-3$ in the dietary lipids did not result in identical ratios in the circulating lipids of both groups.

\section{$20: 4 n-6$ and $22: 6 n-3$}

As shown in table I, the mature sow milk contained rather high amounts of 20:4n-6 $(0.6 \%$ of total fatty acids) and very low amounts of DHA $(<0.1 \%)$. Clearly, the exogenous supply of 20:4n-6 sharply enhanced its level in the intestinal, plasma and cardiac PL of the sow-milk-fed piglets (table IV). This effect was also evidenced in the retinal PE of 14-day-old piglets, but the difference was not significant thereafter. In contrast, the exogenous DHA had no major influence on its status in the heart, blood and peripheral tissues of the sowmilk-fed piglets. At 14 days of age, the level of this fatty acid was even higher in the liver $P L$, brain $P L$, brain and retinal $P E$ of the piglets fed the formula compared to those who received preformed DHA via the maternal milk (table V). At the end of the experiment, the brain PE DHA level remained significantly higher in the formula-fed group.

Correlations between brain and blood fatty acids were examined for the purpose of determining whether circulating lipids could be indicative of the brain DHA status in piglets. It appeared that, within the whole population, the brain DHA was not correlated with the circulating DHA, neither in the RBC PE (fig 3A) nor in the plasma PL (data not shown). However, a negative correlation was found between the brain DHA and the ratio of $18: 2 n-6$ to $18: 3 n-3$ in the RBC PE (fig 3B).

\section{DISCUSSION}

Our study highlights the fact that sow milk and formula cannot be considered as being equivalent in terms of the true availability of PUFA. Even though both diets presented 


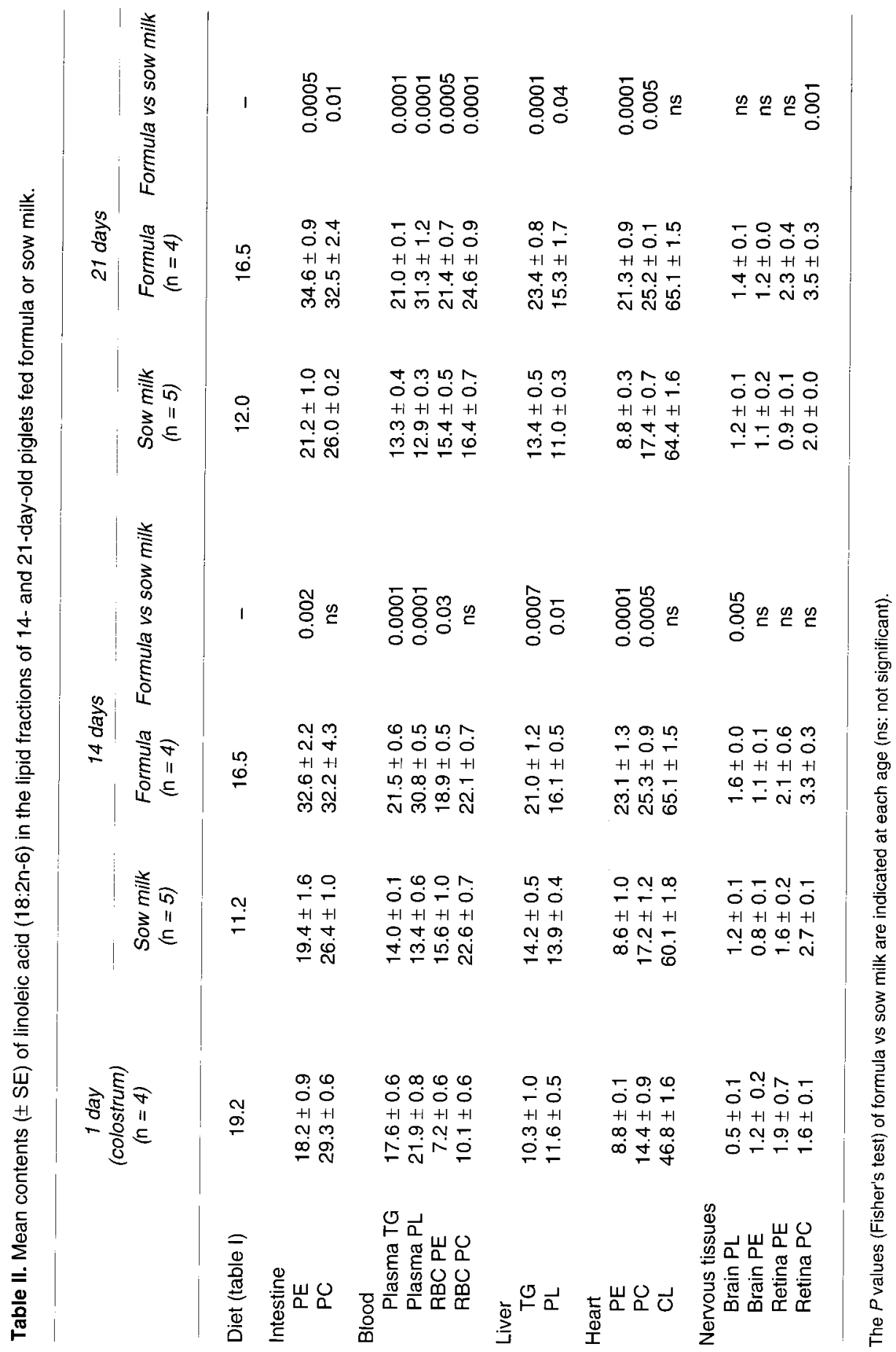


Fatty acid status in piglet fed natural milk or formula

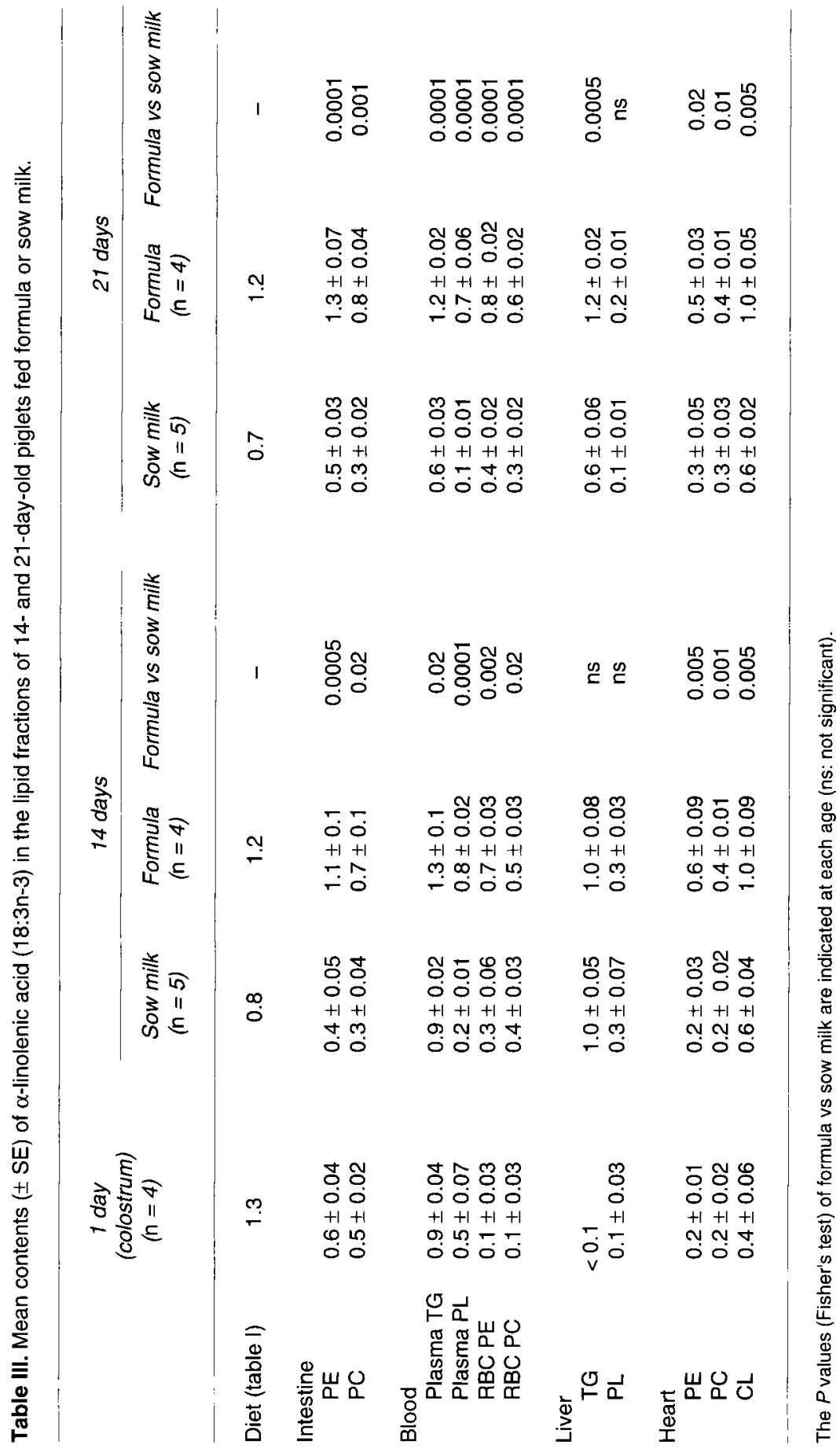




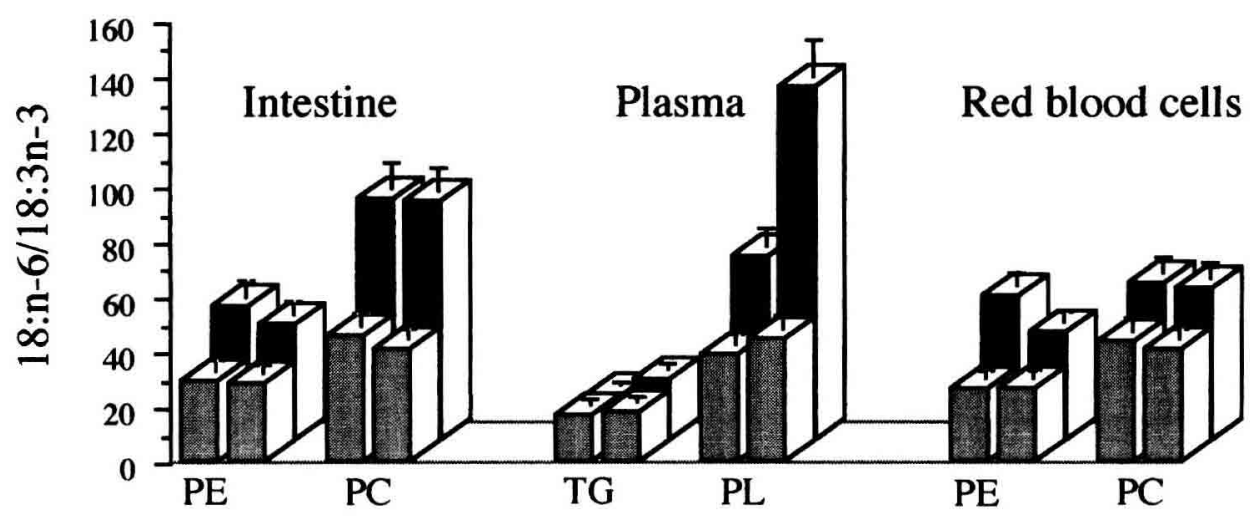

Fig 2. Ratio of 18:2n-6 to $18: 3 n-3$ in the intestine, plasma and RBC of 14-day-old piglets (left part of the coupled histograms) and 21-day-old piglets (right part of the coupled histograms), fed the formula (grey histograms) or sow milk (black histograms). At each age, the difference between the formula and sow milk was significant $(P<0.003$, Scheffe $F$-test) in all the PL samples. The difference in plasma TG was significant $(P<0.002)$ only in the 21 -day-old piglets. The $18: 2 n-6 / 18: n-3$ ratio was equal to $14-15$ in both diets.

the same balance between the essential precursors, an increase in the 18:2n-6/ $18: 3 n-3$ ratio was found in the intestinal $P L$ and circulating lipids of piglets fed natural milk compared to those receiving the formula (fig 2). It has been reported that maximum accretion of DHA in the developing neural tissues depends on the balance between both precursors in milk, owing to their competition for the enzymes of metabolic conversion (review: Koletzko, $1992)$. High values of this ratio (18:2n$6 / 18: 3 n-3=35$ ) in milk replacer diets have been shown to induce a DHA subdeficiency in the piglet's brain (Hrboticky et al, 1990; Arbuckle et al, 1994). Besides, increasing ratios in the maternal milk regularly decreased the accretion of DHA in the
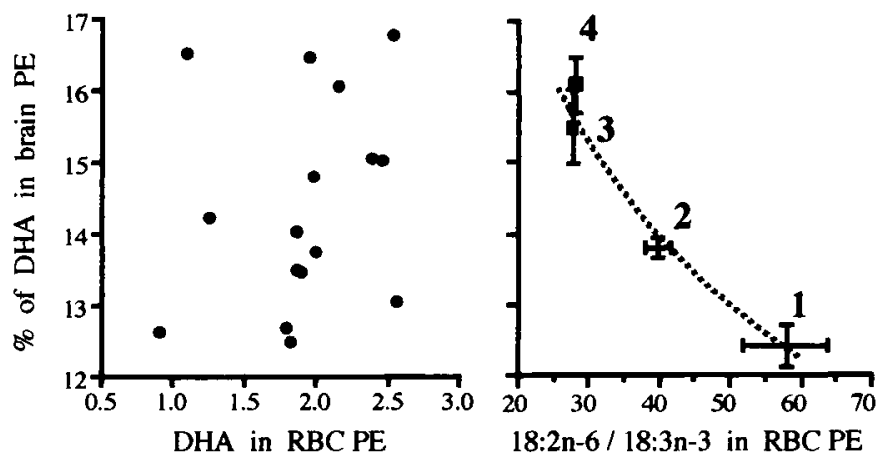

Fig 3. Left: absence of correlations, within the whole population (regardless of age and diet; $n=18$ ), between the level of DHA in brain and the level of DHA in RBC PE. Right: negative correlation between the brain DHA and the ratio of $18: 2 n-6$ to 18:3n-3 in RBC PE. Mean values ( \pm se) of maternally fed piglets at the ages of 14 (point $1 ; n=5$ ) and 21 days (point $2 ; n=5$ ) and formulafed piglets at the ages of 21 (point $3 ; n=4$ ) and 14 days (point $4 ; n=4$ ). 


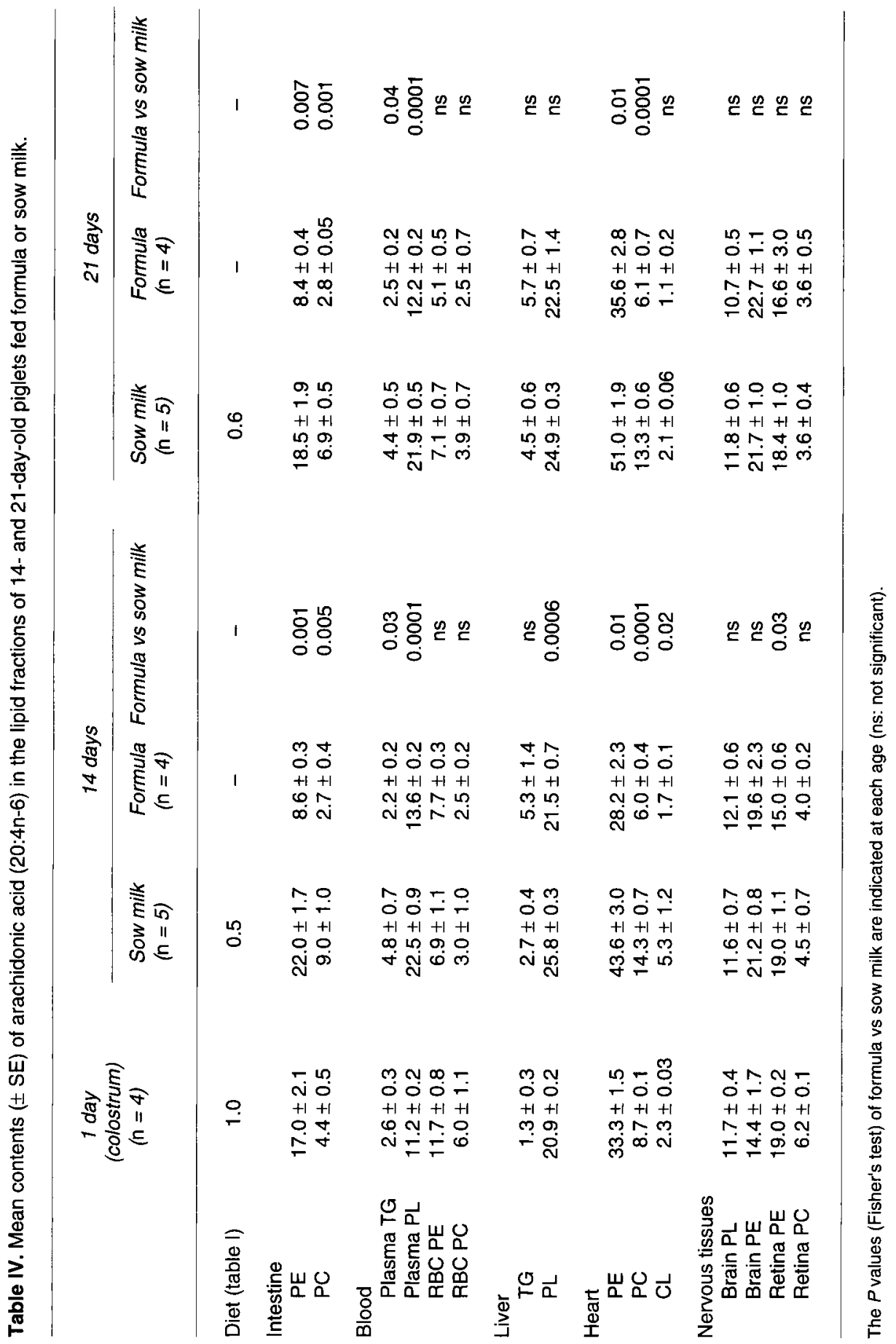




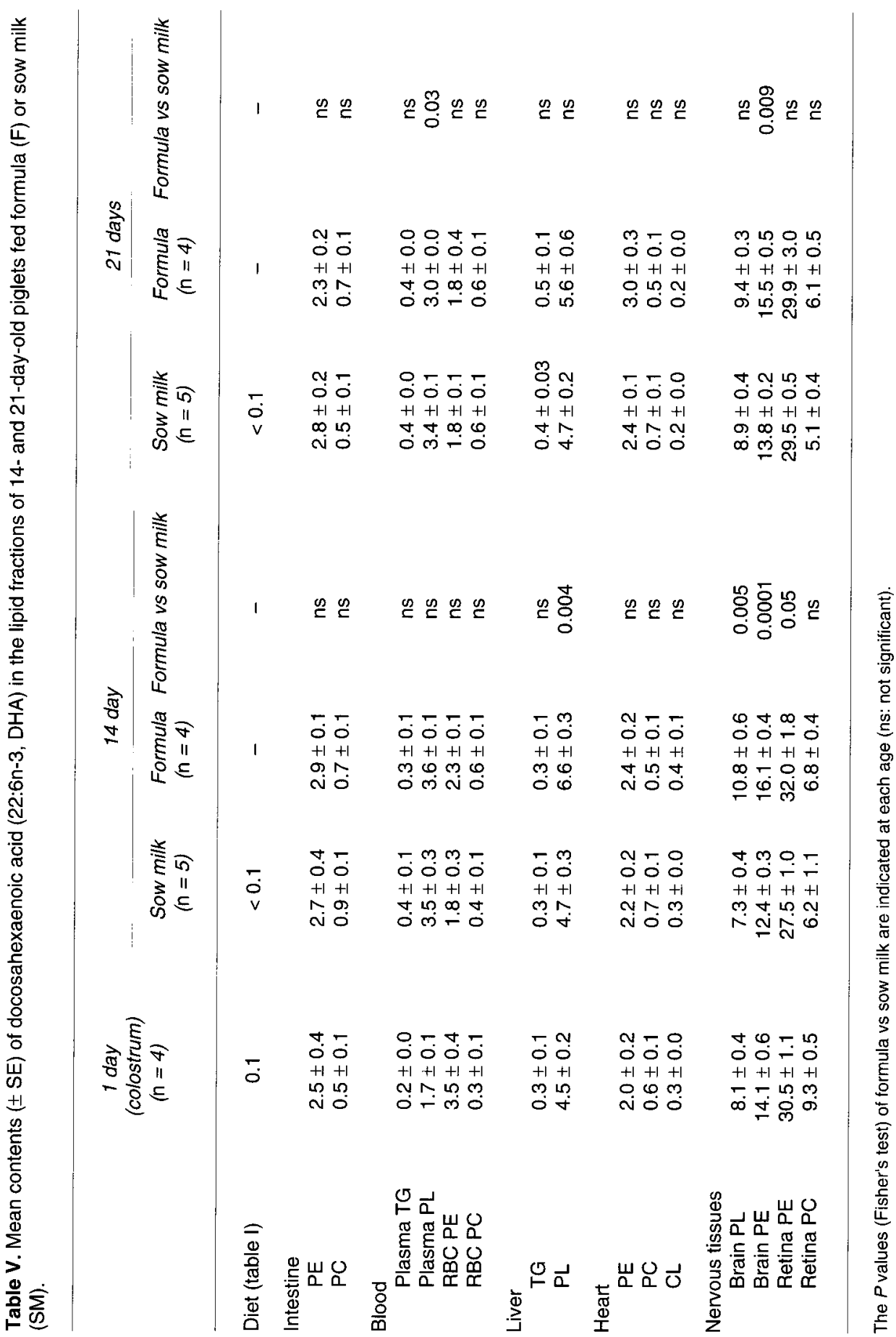


developing brain of suckling rats, notwithstanding the normal supply of DHA in the milk (Guesnet et al, 1995). With these data in mind, the lower $18: 2 n-6 / 18: 3 n-3$ ratio found in the circulating lipids of the formulafed piglets, can be considered as being in favor of the accretion of DHA in the nervous tissues of these animals. The negative correlation between the brain DHA level and the 18:2n-6/18:3n-3 ratio in the RBC PE (fig 3B) supports the idea that the precursor balance regulates the deposition of DHA in the brain. All things considered, the brain DHA level was lower in the natural-milk-fed group, even though the sow milk supplied this preformed fatty acid. This result shows that the exogenous supply of sow milk DHA was not sufficient to alleviate the unfavorable balance of the $18: 2 n-6 / 18: 3 n-3$ ratio in the circulating lipids of the maternally fed piglets. Actually, our reference sow milk must be considered as supplying rather negligible amounts of DHA, and the data support the finding that natural milks with low DHA may not ensure maximum deposition of this fatty acid in the brain of developing piglets (Arbuckle and Innis, 1993). In addition, it appears that the substantial supply of other LC-PUFA in the sow milk (20:3n-3 and 22:5n-3) cannot compensate for the low amounts of preformed DHA.

The reasons behind the apparent enhancement of 18:3n-3 availability in formula feeding are hypothetical as yet. It is possible that dietary $18: 3 n-3$ was more readily absorbed from the formula than from natural milk, owing to different positional distributions in the TG of both diets. Different absorption rates could thus explain why the 18:3n-3 level in the intestinal PL of formulafed piglets corresponded exactly to the proportion of 18:3n-3 in the formula TG (1.1-1.3 vs $1.2 \%$ ), whereas this level was slighty lower in the intestinal PL of maternally fed piglets than in the sow milk TG $(0.4-0.5$ vs $0.7-0.8 \%$ ). Besides, one basic difference between milk replacers and natural milks is the considerable amount of short- and medium-chain TG present in the vegetable fat blends used for the milk formulations. The formula contained $16 \%$ of total fatty acids as $\mathrm{C6:0}$ to $\mathrm{C} 12: 0$, which were absent from the sow milk. As previously suggested, the preferential portal venous transport and oxidation of these fatty acids could spare dietary PUFA from oxidation for energy, and hence, enhance their bio-availability for metabolic conversion (Wall et al, 1992; Innis et al, 1993a, b).

The intestinal and cardiac lipids contained from 1.5- to three-fold more 20:4n-6 when piglets were maternally fed, demonstrating that the exogenous supply of preformed 20:4n-6 in the sow milk influenced its level in some tissues. It must be noted, however, that in the liver, which is the major organ responsible for the metabolic conversion of precursors into LC-PUFA derivatives, the $20: 4 n-6$ level was nearly the same whether the piglets received this fatty acid from their diet or not (table IV). The data on the whole support the hypothesis that formula-fed piglets have the ability to synthetize LCPUFA, DHA and 20:4n-6. Contrasting with the DHA status, the 20:4n-6 level in the brain was not altered by the diet. The brain was thus poorly responsive to an over-supply of preformed $20: 4 n-6$, and highly sensitive to the limited availability of $18: 3 n-3$, the essential precursor of DHA.

In summary we conclude that, firstly, the low content of preformed DHA in the sow milk had no effect on the deposition of this fatty acid in the brain and retinal PL of suckling piglets, and neither had the presence of intermediate LC-PUFA, 20:3n-3 and 22:5n-3. It seemed that dietary DHA levels must exceed $0.1 \%$ of total fatty acids to be channeled into the nervous tissues.

Secondly, the relatively high amounts of preformed 20:4n-6 in natural milk enhanced its deposition in the intestine, plasma and heart, but not in the liver or nervous tissues. The data support the current idea that 
exogenous supplies are not necessary to ensure the maximum deposition of $20: 4 n-6$ in nervous tissues, provided that its precursor $(18: 2 n-6)$ is supplied in sufficient amounts and in adequate balance with the n-3 PUFA. However, the necessity to supplement formulas with 20:4n-6 must not be neglected, if we consider the higher 20:4n6 level found in the cardiac tissue of the maternally fed piglets as optimum.

Finally the $18: 2 n-6 / 18: 3 n-3$ ratio in the circulating lipids was lower in the case of formula feeding, even though the precursor ratios were similar in both diets. Parallel to LC-PUFA enrichment, the positional distribution and metabolic sparing of precursors can be two key elements for optimizing the formulation of the fat blends used in infant formulas.

\section{ACKNOWLEDGMENTS}

The authors are grateful to $\mathrm{J}$ Thévenoux, $\mathrm{F}$ Houlier and A Linard for their technical assistance, and to JP Richard for the management of the rearing unit. We acknowledge the kindness of JM Antoine (Groupe Danone), and the contribution of A Galent (Diépal-nsa) for providing the formula. We also wish to thank $E$ Thompson for correcting the English manuscript. $B$ Goustard is the recipient of a joint grant from the Institut national de la recherche agronomique and the Groupe Danone. This work was supported in part by grants from the MESR program 'Aliment Demain' (No 94 G 0080).

\section{REFERENCES}

Alessandri JM, Joannic JL, Durand G (1993) Polyunsaturated fatty acids as differentiation markers of rat jejunal epithelial cells: a modelling approach. J Nutr Biochem 4, 97-104

Anderson RE, Benolken RM, Dudley PA, Landis DJ, Wheeler TG (1974) Polyunsaturated fatty acids of photoreceptors membranes. Exp Eye Res 18, 205213

Arbuckle LD, Innis SM (1993) Docosahexaenoic acid is transferred through maternal diet to milk and to tis- sues of natural milk-fed piglets. J Nutr 123, 16681675

Arbuckle LD, MacKinnon MJ, Innis SM (1994) Formula 18:2n-6 and 18:3n-3 content and ratio influence longchain polyunsaturated fatty acids in the developing piglet liver and central nervous system. J Nutr 124, 289-298

Ballabriga A (1994) Essential fatty acids and human tissue composition: an overview. Acta Pediatr 83 (suppl 402), 63-68

Bligh EG, Dyer WJ (1959) A rapid method of total lipid extraction and purification. Can J Biochem Physiol 37, 911-917

Bourre JM, Pascal G, Durand G, Masson M, Dumont O, Piciotti M (1984) Alterations in the fatty acid composition of rat brain cells (neurons, astrocytes, and oligodendrocytes) and of subcellular fractions (myelin and synaptosomes) induced by a diet devoid of $n-3$ fatty acids. J Neurochem 43, 342-348

Bourre JM, François M, Youyou A et al (1989) The effects of dietary $\alpha$-linolenic acid on the composition of nerve membranes, enzymatic activity, amplitude of electrophysiological parameters, resistance to poisons and performance of learning tasks in rat. J Nutr 119, 1880-1892

Bourre JM, Piciotti M, Dumont O (1990) $\Delta 6$ desaturase in brain and liver during development and aging. Lipids 25, 354-356

Carlson SE, Werkman SH, Rhodes PG, Tolley EA (1993) Visual-acuity development in healthy preterm infants: effect of marine-oil supplementation. Am J Clin Nutr $58,35-42$

Chen H, Wiegand RD, Anderson RE (1992) Decreased docosahexaenoic acid levels in retina and pigment epithelium of frogs fed crickets. Exp Eye Res 54, 885-892

Christie WW (1985) Rapid separation and quantification of lipid classes by high performance liquid chromatography and mass (light-scattering) detection. $J$ Lipid Res 26, 507-512

Dobbings J, Sands J (1979) Comparative aspects of the brain growth spurt. Early Hum Dev 3, 79-83

Folch J, Lees M. Sloane-Stanley GH (1957) A simple method for the isolation and purification of total lipids from animal tissues. J Biol Chem 226, 497-509

Guesnet P, Alessandri JM (1995) Acides gras polyinsaturés du lait et développement du système nerveux central du nouveau-né. Cah Nutr Diét 30, 109-116

Guesnet $P$, Couet $C$, Alessandri JM, Antoine JM, Durand $G$ (1995) Effets de la teneur en acide linoléique (18:2n-6) et du rapport 18:2n-6/18:3n-3 des lipides du lait maternel sur le statut en acide docosahexaénoique (22:6n-3) des structures nerveuses (cerveau, rétine) du jeune rat allaité. Ann Pédiatr 42, 289-294

Hrboticky N, MacKinnon MJ, Puterman ML, Innis SM (1989) Effect of linoleic acid-rich infant formula feed- 
ing on brain synaptosomal lipid accretion and enzyme thermotropic behavior in the piglet. $J$ Lipid Res 30 , 1173-1184

Hrbotick YN, MacKinnon MJ, Innis SM (1990) Effect of a vegetable oil formula rich in linoleic acid on tissue fatty acid accretion in the brain liver, plasma, and erythrocytes of infant piglets. Am J Clin Nutr 51, 173182

Innis SM (1993) The colostrum-deprived piglet as a model for study of infant lipid nutrition. J Nutr 123 , 386-390

Innis SM, Quinlan P, Diersen-Schade D (1993a) Saturated fatty acid chain length and positional distribution in infant formula. Effects on growth and plasma lipids and ketones in piglets. Am J Clin Nutr 57, 382-390

Innis SM, King JD, Dyer R, Quinlan P, Diersen-Schade D (1993b) Adipose tissue fatty acids of piglets fed formulae varying in saturated and monounsaturated fatty acids, linoleic and linolenic acid, and with longer chain n-3 fatty acids from fish oil. Nutr Res 13, 929940

Innis SM, Nelson CM, Rioux MF, King DJ (1994) Development of visual acuity in relation to plasma and erythrocyte $\omega 6$ and $\omega 3$ fatty acids in healthy term gestation infants. Am J Clin Nutr 60, 347-352

Juaneda $P$, Rocquelin $G$ (1985) Rapid and convenient separation of phospholipids and non-phosphorus lipids from rat heart using silica cartridges. Lipids 20, 40-41

Koletzko B (1992) Fats for brain. Eur J Clin Nutr 46, S51-S62

Makrides M, Simmer K, Goggin M, Gibson RA (1993) Erythrocyte docosahexaenoic acid correlates with the visual response of healthy, term infants. Pediatr Res 33, 425-427

Makrides M, Neumann MA, Byard RW, Simmer K, Gibson RA (1994) Fatty acid composition of brain, retina, and erythrocytes in breast- and formula-fed infants. Am J Clin Nutr 60, 189-194

Morrison W, Smith L (1964) Preparation of fatty acid methyl esters and dimethylacetals from lipids with boron fluoride-methanol. J Lipid Res 5, 600-608

Neuringer M, Connor WE, Van Petten C, Barstad L (1984) Dietary omega-3 fatty acid deficiency and visual loss in infant Rhesus monkeys. $J$ Clin Invest $73,272-276$

Rose HG, Oklander M (1965) Improved procedure for the extraction of lipids from human erythrocytes. J Lipid Res 6, 428-431

Sweasey D, Patterson DSP, Glancy FM (1976) Biphasic myelination and the fatty acid composition of cerebrosides and cholesterol esters in the developing central nervous system of the domestic pig. $J \mathrm{Neu}$ rochem 27, 375-380

Wainwright $P$ (1992) Do essential fatty acids play a role in brain and behavioral development? Neurosci Biobehav Rev 16, 193-205

Wall KM, Diersen-Schade D, Innis SM (1992) Nonessential fatty acids in formula fat blends influence essential fatty acid metabolism and composition in plasma and organ lipid classes in piglets. Lipids 27, 10241031

Yamamoto N, Saitoh M, Moriuchi A, Nomura M, Okuyama $H$ (1987) Effect of dietary $\alpha$ linolenate/linoleate balance on brain lipid composition and learning ability of rats. J Lipid Res $28,144-151$ 